\title{
Education and the Liberal Arts at the University of Iowa
}

\section{StOW PERSONS}

THE COLLEGE OF EDUCATION at the University of Iowa held a convocation in 1923 attended by notables of the educational world to celebrate the fiftieth anniversary of the establishment of the first university professorship of education in the United States. ${ }^{1}$ For some fifty years thereafter the university catalogs regularly reminded readers that the university had pioneered in the integration of teacher preparation with the liberal arts curriculum. That century-long relationship is the subject of this article.

In 1873 the University of Iowa in effect adopted the principle that the classroom teacher should be a liberally educated person; it was not enough to be a mere technician adept in the ways that children learn and skilled in the methods of teaching. That principle, although continually affirmed by the university, was gradually eroded over the years as the liberal arts faculty lost interest in pedagogics, and the education faculty shifted its principal interest from the preparation of undergraduates for teaching careers to the training of graduate students for careers as school administrators and specialists. $^{2}$

1. Forest Ensign, "Fifty Years of Education in the University of Iowa," University of Iowa, Extension Bulletin \#133 (1 October 1925), 13-14, 47. The University of Michigan and Cornell College both disputed the claim. On the Michigan claim, see Allen S. Whitney, "The First Chair of Education in an American University," School and Society 53 (1941), 257-61. In defense of the Iowa claim, see W. S. Ebersole to E. P. Cubberley, 24 April 1923; H. H. Seerley to Cubberley, 28 May 1923, Jessup Presidential Papers, 192223 , \#100, University of Iowa Archives (hereafter cited as UI Archives).

2. See Jurgen Herbst, And Sadly Teach: Teacher Education and ProfesTHE ANNALS OF IOWA 52 (Spring 1993). (CThe State Historical Society of Iowa, 1993. 
IN THE YEARS immediately following the founding of the university in 1847, teacher preparation had been the university's principal business. The Normal Department, which initially enrolled a substantial portion of the student body, was admittedly not of collegiate grade. However, in those pioneer days, before there were high schools or a normal school to assume the burden of teacher training for the common and graded schools, the university could hardly evade this public responsibility, which in any event was mandated by the legislature. The initial program included work in mathematics, science, history, and English in addition to pedagogics. ${ }^{3}$

President Silas Totten (1859-1862) took the first steps towards defining the character of the university as an educational institution. He believed that the number of teachers needed was too great to justify the diversion of the university's limited resources to teacher training; instead, the university should train teachers of teachers. Totten wanted to incorporate the Normal Department in the Collegiate Department (later Liberal Arts), where students would receive both subject-matter and pedagogical training in order to become teachers in the high schools, academies, and colleges. Those schools and colleges, in turn, would train classroom teachers for the primary and common schools. The trustees were not yet prepared to take this step, but restricted the faculty of the Normal Department to pedagogy. At the same time, they required students in the Normal Department to take substantive work in the Collegiate Department, which had the practical effect of elevating pedagogy to baccalaureate status. ${ }^{4}$

Totten's ambitions for the Normal Department were realized by Stephen N. Fellows, who was appointed professor of didactics in 1867 . It would be difficult to overestimate the

sionalization in American Culture (Madison, WI, 1989); and Merle Borrowman, The Liberal and Technical in Teacher Education (New York, 1956).

3. Homer H. Seerley quoted and discussed the "First Circular of the Normal Department," 19 September 1855, in University of Iowa, Extension Bulletin \#133 (1 October 1925), 25-26. See also Forest Ensign, "The First Century of Teacher Training in the State University of Iowa" (typescript, 1947), 1-47, UI Archives.

4. Ensign, "First Century," 47-48. 
importance of Fellows's work in establishing the place of pedagogics in the university structure. An energetic and aggressive man, he secured his place in the Collegiate faculty by appointment as professor of logic and moral science before implementing the merger of the normal program with the liberal arts. His course in didactics was restricted to seniors in the Collegiate Department who were preparing to become teachers at advanced levels. It was the introduction of this course, in 1873, which was later celebrated as marking the inauguration of collegiate-level instruction in didactics in the United States. ${ }^{5}$

But this was only the first step in Fellows's ambitious plans. He complained to the regents that normal study was already too intimately blended with liberal study. What was needed was a professional department with the same relationship to the Collegiate Department as that enjoyed by the Law Department. Although at that time the professional departments were not yet post-baccalaureate programs, Fellows was proposing a strictly professional program of one year, with admission restricted to those who had completed the "English" sequence, a degree option in the Collegiate Department. ${ }^{6}$ Well in advance of his time, Fellows was pioneering in the mix of liberal and professional studies that would eventually characterize the Iowa program in education.

In several important respects, however, Fellows remained an old-fashioned man. His course in mental philosophy, the discipline out of which psychology was to emerge, remained fixed upon the sterile classification of the mental faculties, and found its authority in metaphysics rather than in experimental work. His commendable effort to raise the standards of the pedagogical program to collegiate grade was largely frustrated by his moral censoriousness, which factionalized the faculty and undoubtedly strengthened the prejudice against the education program within the Collegiate faculty. ${ }^{7}$

5. S. N. Fellows to Board of Regents, 23 June 1870, Normal Department, "Reports" folder, MS file, Ser. 1, M-N, UI Archives; Amos N. Currier, "Professor Stephen Norris Fellows, D.D.," Iowa Alumnus 5 (June 1908), 241-42.

6. Ibid.

7. S. N. Fellows, "Didactics in the State University of Iowa," Education 1 
Mounting turmoil within the faculty over a number of issues led in 1886 to the dismissal of several professors, including Fellows. His successor was George T. W. Patrick, whose status as professor of mental and moral science and didactics marked another step in the developing relationship between education and the liberal arts. Patrick's primary identification was with the Collegiate faculty. In this respect his brief tenure as professor of didactics represented the full fusion of the liberal and the professional at Iowa. His psychology, unlike that of Fellows, was up to date, reflecting his graduate study at Johns Hopkins with G. Stanley Hall, and his familiarity with the German psychological laboratories. The laboratory he opened at Iowa in 1890 was one of the first in the country. Although he made no attempt to identify himself with the community of professional educators, and was regarded by his friend Forest Ensign as a failure in his role as professor of didactics, Patrick was a pioneer at lowa in pointing toward the physiological and psychological foundations of educational theory which were to play an important part in pedagogy down to the present day. ${ }^{8}$

Frederick E. Bolton, who joined the Iowa education faculty in 1900, had also studied with G. Stanley Hall, and he shared Patrick's belief in the central role of psychology in pedagogy. Fellows and Patrick had both been philosophers, epitomizing the close association of philosophy with pedagogy characteristic of the earliest programs in education as they had emerged not only at Iowa but also in several other colleges and universities. Bolton, on the other hand, as an educational psychologist represented the shift toward a more specialized approach to the subject. His introductory course in General Pedagogy began with "the psychological bases of

(1881), 393-400; Seerley, "First Circular," 30-31; Seerley to Cubberley, 24 April 1923, Jessup Presidential Papers, 1922-23, \#100, UI Archives. One of the fault lines separating the old university from the new can be traced in Fellows's scornful comments on President Charles Schaeffer (18871898). Schaeffer, he complained, smoked tobacco, danced, played whist, had a billiard table in his home, served wine to his dinner guests, and was married to a New Yorker who moved in "high life." Fellows to J. S. Clarkson, 17 February 1888, Fellows file, UI Archives.

8. F. Ensign to G. T. W. Patrick, 6 June 1945, Patrick Papers, UI Archives. 
the principles of teaching." He also offered a course in child study, while Patrick, now in charge of philosophy and psychology, taught a course in the psychology of the child. ${ }^{9}$ The study of psychology was thus cementing its place as the crucial link between education and the liberal arts, gradually replacing the older association with the humanistic subjects.

President George MacLean (1899-1911) reorganized the institutional structure of the university by introducing the modern colleges, schools, and departments. The Collegiate Department became the Liberal Arts College, and education became briefly a department of that college. MacLean also encouraged the formation of schools within Liberal Arts. Engineering, commerce, and education shortly became schools and eventually achieved full collegiate status. For the purpose of offering undergraduate courses, education retained its departmental status in Liberal Arts, and education faculty members enjoyed joint membership in both faculties. At the same time, the organization of the Graduate College clarified the distinction between undergraduate and graduate degree programs, and helped to foster the identification of professionalism with postbaccalaureate programs. The institutional structure now in place impelled the growing distinction between the liberal and professional in education. ${ }^{10}$

AFTER BOLTON BECAME DIRECTOR of the School of Education in 1907, he was fully occupied with organizing it and establishing its relationship with the liberal arts. He believed firmly in "the dignity and worth of the scientific study of education as one of the liberal arts," and he acknowledged the danger that the creation of separate schools or colleges of education might result in the loss of the sense of education as a liberal discipline. He hoped that the study of education as one of the liberal arts would attract many students who had no intention of becoming teachers. In practical terms, the Department of the Science and Art of

9. University of Iowa Catalog (hereafter cited as UI Catalog), 1900-1901, 114, 117.

10. Stow Persons, The University of Iowa in the Twentieth Century (Iowa City, 1990), 25-34, 57-63. 
Education continued to offer undergraduate courses in the Liberal Arts College. This department was to train high school teachers, while the School of Education would "correlate all the forces of the university which contribute professionally to the preparation of educational leaders in high schools, normal schools, colleges, and city superintendencies." In other words, high school teachers should be liberally educated, while administrators should in addition have a professional education. ${ }^{11}$

Bolton estimated that some 70 percent of all juniors and seniors at Iowa in 1907 expected to become teachers. Their preparation required careful attention. The student should major in the subject-matter field of choice, and should also take introductory courses in at least five of the subjects taught in high school, as well as the necessary pedagogical work. By way of emphasizing the intimate relationship between the liberal and the professional, the catalog noted that courses specially designed for prospective teachers were offered in English, German, Greek, Latin, fine arts, history, and mathematics. ${ }^{12}$ This was the origin of what would become a major feature of the lowa program, namely, the location in the subject-matter departments of course work that combined subject matter with introductory pedagogical training. ${ }^{13}$ Bolton was able to persuade the liberal arts faculty to grant him authority to approve such courses for teacher training purposes even when the courses offered by senior professors in their respective departments lacked much pedagogical content. Although the professors were listed in the catalog as members of the education faculty, they were not joint appointees in any true sense of the term.

11. Frederick E. Bolton, "Relation of the Department of Education to Other Departments in Colleges and Universities," Journal of Pedagogy 19 (19067), 137-76; UI Catalog, 1907-1908, 269.

12. UI Catalog, 1902-1903, 132-33; F. E. Bolton, "The New School of Education in the State University of Iowa," Iowa Alumnus 5 (October 1907), 1-7.

13. A later education dean, Paul Packer (1923-1946), apparently unaware of these earlier developments, dated the plan from 1912, when Walter Jessup became dean. P. Packer, "The Iowa Plan for Teacher Training," Journal of Higher Education 3 (1932), 493-95. 
The arrangement was far from being wholly satisfactory. Bolton suspected, probably correctly, that many liberal arts faculty members were contemptuous of methods courses, holding the common view that teaching was an "art" requiring no formal preparation beyond mastery of the subject matter. He assumed that they tolerated such courses in their departments as preferable to leaving them to the education faculty. Bolton believed that ideally the methods courses should be taught by scholars who were well grounded in educational psychology and conversant with the best methods of teaching their respective subjects. They should also have had extensive experience teaching their subjects in high school. ${ }^{14}$ The latter expectation would, of course, have eliminated the subject-matter scholars recruited by the subjectmatter departments, since they would rarely if ever have had high school teaching experience. Bolton's proposal seemed to imply either a significantly different set of criteria for the appointment of liberal arts faculty members, or the transfer of methods courses to the education faculty. Because he thought of education as a liberal discipline, the latter alternative was probably a welcome prospect to him; in that case he would have controlled the appointment of such faculty members. A committee of deans wrestled with the problem of "unification of the School [of Education] and the College," but nothing seems to have come of its labors. ${ }^{15}$

Bolton apparently expected MacLean to elevate the School of Education to full collegiate status and to make him its dean. But before this could occur, MacLean was dismissed, and his successor, John W. Bowman, not only refused to take that step, but even gave some thought to abandoning the education program entirely. Bolton resigned in 1912 to become dean of education at the University of Washington.

With Bolton's departure and the arrival of Walter Jessup, the School of Education was promptly elevated to collegiate status. It was clear that status itself was not the issue; but rather, what kind of college it should be, and how it should

14. Bolton, "Relation," 148-52.

15. F. Ensign, "Placement of Teachers" (typescript, n.d.), Educational Placement Office, historical files, 1922-1968, box 1, UI Archives. 
relate to the Liberal Arts College. As dean, Jessup emphatically rejected Bolton's proposals and reaffirmed the existing relationship between the two programs. Iowa was not to go the way of the Teachers College at Columbia, or the universities of Missouri, Minnesota, or Indiana, where the teachers colleges furnished the entire curriculum for their students.

Shortly elevated to the presidency, Jessup was in a position to fasten his views on the institution. The College of Education's undergraduate program to train high school teachers was to consist of a major in liberal arts or commerce and professional work in education. The bachelor's degree would be granted by the subject-matter college, with a diploma from the College of Education. The graduate program would consist primarily of professional work together with appropriate subject matter. Advanced degrees would be conferred by the Graduate College, with a diploma in education. ${ }^{16}$ The distinction between the liberal and the professional was blurred by the introduction of an undergraduate liberal arts major in education requiring twenty-four hours of professional work. This program was to serve the need for superintendents and teachers of pedagogy in the normal training programs of the high schools. Although they were listed in the section of the catalog titled "NonProfessional Courses" (that is, liberal arts), such offerings as "Methods of Teaching High School Subjects," "School Supervision," "The High School Curriculum," and "Supervision of Special Subjects" were clearly professional in character.

Apart from such intrusions, the ideal arrangement as Jessup envisioned it provided for a liberal arts faculty member who was at once a specialist in the subject-matter field and also qualified in pedagogics. Such individuals would hold joint appointments in the two colleges and would offer courses that would satisfy the expectation of subject-matter competence as well as pedagogical expertise. In practice, such faculty were not easy to find. The senior faculty members

16. [Jessup], untitled draft, n.d., "Education" folder, MS file, Series 1, D-G, UI Archives. 
who originally offered these courses gradually gave way in several departments to newly appointed individuals, usually of junior rank, who presumably possessed the dual qualifications. The most successful of these appointments occurred after 1916, when the newly organized university elementary and high schools made possible the appointment of scholarly individuals actually engaged in high school and college teaching. Bessie Pierce in history and M. F. Carpenter in English represented the plan at its best. Over the years, however, the continuing hostility or indifference to education among many liberal arts faculty members had the effect of limiting such joint appointments to departments where the emphasis on research was not paramount.

It was Jessup who summoned the distinguished conferees in 1923 to celebrate the half-century of fruitful collaboration between the liberal and the professional in the training of teachers at Iowa. Two of the speakers, however, took direct exception to the Iowa plan. Dean James E. Russell of Columbia Teachers College confirmed President MacLean's prediction a quarter of a century earlier, namely, that the American university was becoming a collection of professional schools, leaving the undergraduate liberal arts program in an anomalous position. "The academic college," Russell declared, "is becoming, by virtue of the elective system, either a preprofessional school or an eddy wherein the debris of the university currently enjoys the lazy round of social and athletic pleasures." Scornfully dismissing the existing mix of liberal and professional studies in the liberal arts college, Russell opted for a wholly separate education faculty that would combine "the best cultural education obtainable" with the best kind of professional training for educators. Elwood P. Cubberley of Stanford carried Russell's vision a step further when he observed that the most important function of a university's college of education had become the training of educational administrators rather than teachers. Attention should now be directed to such questions as state policy on the types of instruction to be offered, school financing, health care, compulsory attendance, adult education, Americanization, vocational training, and the problems of a one-class school 
system. The training of teachers should be left to the normal schools. ${ }^{17}$

IN SPITE OF THESE DISSENTING OPINIONS, Jessup and his successors were determined to maintain the distinctive Iowa plan. By 1927, there were some 782 prospective teachers majoring in various liberal arts departments, but only forty education majors. The latter, in Dean Paul Packer's opinion, were the ablest of all undergraduates. These were the students preparing to be educational administrators. As for the others, who were preparing to be classroom teachers, many were judged to be of such poor quality that Forest Ensign was charged with the task of screening out the worst of them. ${ }^{18}$ Here was ominous evidence of the emerging distinction between capable administrators and inept teachers. It was certainly ironic that while the educators publicly celebrated their association with the liberal arts, privately they were complaining about the poor quality of the students they were obliged to draw from that college.

Undergraduates preparing to become teachers had traditionally majored in one of the subject-matter departments. In 1942, however, an undergraduate major in education in the Liberal Arts College was introduced. The principal concentration consisted of twenty-four hours of work in education courses, together with any other course work required for a particular type of teaching certificate. Other required work was to be distributed among the natural science, social science, and humanities divisions of the liberal arts program. Under this degree option, the chief emphasis shifted from liberal to professional training under the auspices of the education faculty. This major represented further erosion of the association of pedagogics with the liberal arts.

For many years, the principal business of the undergraduate education program had been the preparation of high

17. University of Iowa, Extension Bulletin \#133, 49-56.

18. As recently as 1954, a report by the American Association of Colleges for Teacher Education found the Iowa pattern unique. P. Packer to E. Gilmore, 15 August 1938, Gilmore Presidential Papers, 1937-38, \#35; Ensign, "Teacher Training," 490-94; P. Packer to H. M. Torey, 23 November 1927, Jessup Presidential Papers, 1927-28, \#36, UI Archives. 
school teachers. The training of elementary school teachers had been left to the Normal School at Cedar Falls. The university's Experimental Elementary School, organized in 1915, was intended to train supervisors, principals, and superintendents, but not elementary classroom teachers. ${ }^{19}$ However, with the successive transformations of the Normal School into a teachers college, a state college, and finally a state university with ever expanding functions, the tacit division of programs gave way to competing or overlapping missions. Dean Elmer T. Peterson recommended in 1951 that in the absence of any coordination of programs among the state institutions the University of Iowa must be aggressive in protecting its stake in teacher education, especially at the elementary level. ${ }^{20}$ With the support of the Iowa Commission on Teacher Education, which acknowledged that the Cedar Falls institution was unable to train the number of elementary teachers needed, the university inaugurated a four-year bachelor of arts program leading to an Advanced Elementary Teaching Certificate. ${ }^{21}$ Following the adoption of this program, the number of elementary teachers placed annually increased from 52 in 1952 to 318 in $1970 .{ }^{22}$

At the same time, placement of teachers in junior and senior high schools leveled off and began to decline. In 1928, the earliest year for which data are available, the university placed 534 junior and senior high school teachers. After a sharp drop in the depression-plagued 1930s, the placement

19. F. Ensign, "Placement of Teachers."

20. E. T. Peterson to E. Horn, 5 January 1951, Horn Papers, box 27, folder 9, UI Archives. The formal preparation of elementary school teachers had been abandoned in 1873. Informally, however, it had continued on an individual basis. Thus between 1902 and 1906, when the Liberal Arts faculty voted to abolish the practice, the degree of bachelor of didactics was conferred on twelve individuals. Ensign, "Placement of Teachers"; Liberal Arts faculty minutes, 9 June 1902, 8 June 1904, 12 June 1905, 14 February 1906, UI Archives.

21. "Memorandum on Undergraduate Elementary Teacher Preparation at the State University of Iowa" (typescript, Hancher Presidential Correspondence, [1952]), 1952-53, \#42, UI Archives.

22. Educational Placement Office, Annual Reports, 1 October 1951-1 October 1952; ibid., 1970, box 7, UI Archives. After 1975, the reports no longer separated elementary school from other teacher placements. 
of high school teachers reached its peak with 660 in 1939. By 1974, the number had decreased to $343 .^{23}$ Thereafter, the combined numbers of elementary and high school teachers hardly equaled the earlier placements in high schools alone. In recent decades there has also been a sharp increase in the number of placements in special education-individuals trained to deal with "exceptional" students, mostly those with disabilities and behavioral disorders, but also gifted students. ${ }^{24}$ The College of Education, meanwhile, focused its attention more narrowly on its graduate program for the training of school administrators as the placement of teachers leveled off and then declined.

The preparation of students for teaching science in elementary and secondary schools illustrated the widening gulf between education and the liberal arts. At the turn of the century, the College of Liberal Arts offered special courses for teachers in mathematics and several of the science departments, including biology, chemistry, and physics. These courses required some prior work in the subjects, on the reasonable assumption that the student should know something of the science before learning how to teach it. The gradual disappearance of these methods courses reflected both the lack of interest in pedagogy on the part of scientists as well as the preference of the public schools for more superficial courses in general science rather than the rigorous work of the specific sciences. The educators responded by developing programs in science education under their own auspices.

The enormous growth of the elementary and secondary schools in the first half of the twentieth century presented educators for the first time with large numbers of uninterested and intractable students whose presence in the classroom forced a reconsideration of traditional expectations. High schools that had formerly offered courses in biology, chemistry, and physics in addition to mathematics, and had needed teachers qualified to teach various combinations of

23. Committee on Recommendation of Teachers, 15 February 1928-15 February 1929; Educational Placement Office, Annual Reports, 1922-1942, 1974, box 8, UI Archives.

24. Data on placement of special education teachers begin in 1975 . 
these disciplines, often replaced these "hard" courses with general science, a superficial mix of disciplines with an emphasis on practical applications. ${ }^{25}$ To meet the need to prepare students to teach general science, the College of Education as early as 1933 appointed a faculty member who offered special courses for prospective teachers. One was called "Methods of High School Science"; a similar course was offered in mathematics. Beginning in 1949 a bachelor's degree program in general science provided for introductory study in three sciences together with pedagogical courses to satisfy the requirement for the secondary teaching certificate. This program was offered in the Liberal Arts College but administered by education faculty members. ${ }^{26}$

The general science program served undergraduates only, until a graduate program in science education was introduced in 1972, offering master's and doctoral degrees. The M.S. degree without thesis, designated the most appropriate program for classroom teachers, required twenty-six semester hours of graduate work in two or more sciences, with a minimum of ten hours each in two of them. Education faculty members offered courses in the history and philosophy of science. Eventually, the general science program was abandoned, and science education was extended to include an undergraduate major. The student was required to choose one of six sciences for special emphasis together with work in the history and philosophy of science. One of the six science areas was general science, so that the student choosing this area could complete degree requirements having taken relatively little work in the physical or biological sciences. ${ }^{27}$ The preparation of science teachers was now largely separated from work in the liberal arts.

25. General science was being taught in one-fifth of the reporting schools. in lowa in 1915. Edward A. Krug, The Shaping of the American High School (New York, 1964), 372-73.

26. UI Catalog, 1949-50, 76. This program was also available to premedical, predental, and other preprofessional students. Robert E. Yager, "Science Education at the University of Iowa, Twenty-five Years, 1950-1975," Special Report One, Science Education Center, University of Iowa, October 1975, UI Archives.

27. UI Catalog, 1990-92, 313-14. 
As science went, so went social science. The forces that produced instruction in social studies in the schools were similar to those that produced general science. In the early decades of this century, there was a growing sense of the inadequacy of the traditional teaching of history as the chronology of public events, leaving students with no understanding of the forces at work in public life. A broad range of social, economic, and cultural topics was introduced to fill out the historical framework in the expectation that students would be induced to cultivate "critical thinking." At Iowa, the individual who inaugurated the training of teachers for this field was Bessie Pierce. In 1919 she was appointed instructor in history and head of social studies in the University High School. She also offered a course in the university's history department on the teaching of history. Beginning in 1925, this course was cross-listed in the College of Education as "Social Studies." In the same year, the University High School courses in history and geography were combined as "Social Studies." 28

Although Pierce was and remained a historian, her courses at Iowa were notable for their combination of economic and social material. ${ }^{29}$ When Ernest Horn, the founder of the University Elementary School, published his Methods of Instruction in the Social Studies in 1937, he reaffirmed the view that history furnished the time frame binding all of the social studies into a workable unity. Following Pierce's departure for the University of Chicago, her successors, Howard Anderson and John Haefner, who were also trained in history, continued to teach the social studies course. But the other liberal arts departments relevant to the social studies, namely, political science, geography, economics, and sociology, did not participate in the program. What might have been an interdisciplinary effort to support and develop the social studies did not emerge, and history was left to provide

28. UI Catalogs, 1918-1928; Virginia Westerberg, "A History of the University Elementary School, State University of Iowa, 1915-1958" (Ph.D. diss., University of Iowa, 1959).

29. Detailed outlines of Pierce's courses for high school students are found in University of Iowa, Extension Bulletin \#97 (1924-25), $188 \mathrm{ff}$. 
the link to the liberal arts. The history faculty itself did not attach great value to the program, and in 1949 the joint appointment in history and education was terminated with Haefner's transfer to the education faculty.

Under the deanship of Howard R. Jones (1962-1980), the College of Education continued to emphasize its traditional relationship with the liberal arts. The catalog announced that "the curriculum is based upon the assumption that the teacher should have a broad and liberal education, that he should be master of the subject or group of subjects which he expects to teach, and that this preparation should be paralleled by professional education which should provide a knowledge of the nature of the learner and the learning process." ${ }^{30}$ Although the methods courses for the teaching of high school subjects were now located in the College of Education, the catalog emphasized that eighteen of the twenty-two professors who taught these courses had received their Ph.D.s in the subject-matter discipline and held rank in both the Education and Liberal Arts faculties. ${ }^{31}$ Further inspection, however, reveals how the relationship between the two faculties was evolving. Three of the eighteen joint appointees were in art, and three in physical education; two each in library science, mathematics, and statistics; and one each in English, French, German, music, psychology, and speech. There were none in the physical or biological sciences or the social sciences. The joint endeavors of the two colleges were now confined to what might broadly be called skills subjects.

When Charles Case succeeded Jones as dean in 1980, the traditional affirmation of intimate association with the liberal arts was abandoned in favor of a statement tracing the historical evolution of the education program from department to school to college, with emphasis on its emerging autonomy. The Liberal Arts College still offered undergraduate education majors, but admission to these majors was controlled by the College of Education, which set superior requirements for

30. UI Catalog, 1963, 218.

31. UI Catalog, 1970-72, 231. 
admission. ${ }^{32}$ At the same time, there was a constantly increasing emphasis on the graduate program in education.

THE EVOLVING RELATIONSHIP between the liberal and the professional at the University of Iowa passed through two distinct phases. The principle of the incorporation of professional training in the liberal arts program dated from the work of Stephen Fellows, beginning in 1873. But with the organization of the School of Education in 1907, with its promise of an autonomous education faculty and program, the continued association of the liberal and the professional was ensured primarily by joint appointments of faculty members who combined these elements in their teaching. However, the number of such joint appointees, especially in fields central to the liberal arts tradition, has gradually diminished. Although they appear not to have been aware of it, those who convened the convocation of 1923 were celebrating an event of largely historical significance.

Responsibility for the gradual erosion of the relationship rested with both faculties. There were always liberal arts faculty members who were hostile or indifferent to the education of teachers in the Liberal Arts College. These scholars and scientists believed firmly in the superior value of their specialties in the university setting, and were prepared to "skim the cream" of the student body, leaving the rest to allegedly less exacting programs for which they assumed no collegiate responsibility. The educators for their part were content to introduce a succession of technical or professional options which had the effect of diluting the liberal content of undergraduate education for prospective teachers. Neither faculty was willing to make the joint effort necessary to provide an ongoing teacher education program that combined a thorough liberal education with the necessary pedagogical training.

32. UI Catalog, 1990-92, 297. 
Copyright of Annals of Iowa is the property of State of Iowa, by \& through the State Historical Society of Iowa and its content may not be copied or emailed to multiple sites or posted to a listserv without the copyright holder's express written permission. However, users may print, download, or email articles for individual use. 